Jessica Wiskus*

\title{
On Music, Order, and Memory: Investigating Augustine's Descriptive Method in the Confessions
}

https://doi.org/10.1515/opth-2020-0116

received January 3, 2020; accepted April 21, 2020

\begin{abstract}
Augustine's account in the Confessions Book IX of his ecstasy at Ostia remains unsurpassed in its poetic force, yet unusual, as a description of religious experience, in two particular respects. First of all, what he describes is not a "vision" of God, but an experience of listening. Second, it is not a solitary but a shared experience (e.g., with his mother, Monica). This essay considers the significance of these two elements by analyzing the relation between his description in Book IX and the understanding of rhythm that he develops in De musica. Drawing also on Book X (on memory) and Book XI (on time-consciousness) in the Confessions, I investigate a particular type of flowing memory - what I call, "perfect” memory - that characterizes the temporally ordered movements of musical rhythm, showing that it is in this type of memory that Augustine finds God.
\end{abstract}

Keywords: memory, rhythm, number, music, measurement, time-consciousness, God, happiness, anamnesis, De musica

As a description of religious experience, unforgettable is the passage from Book IX of the Confessions - the passage where Augustine and his mother, speaking together at Ostia on the Tiber River, exclaim of their experience of God: ${ }^{1}$

\begin{abstract}
Therefore we said: If to anyone the tumult of the flesh has fallen silent, if the images of earth, water, and air are quiescent, if the heavens themselves are shut out and the very soul itself is making no sound and is surpassing itself by no longer thinking about itself, if all dreams and visions in the imagination are excluded, if all language and every sign and everything transitory is silent - for if anyone could hear them, this is what all of them would be saying, "We did not make ourselves, we were made by him who abides for eternity" (Ps. 79:3, 5) - if after this declaration they were to keep silence, having directed our ears to him that made them, then he alone would speak not through them but through himself. We would hear his word, not through the tongue of the flesh, nor through the voice of an angel, nor through the sound of thunder, nor through the obscurity of a symbolic utterance. Him who in these things we love we would hear in person without their mediation. That is how it was when at that moment we extended our reach and in a flash of mental energy attained the eternal wisdom which abides beyond all things (Confessions 9.10.25).
\end{abstract}

Could we understand their experience at Ostia in terms of a vision? Certainly not: for here, "all dreams and visions in the imagination are excluded." And though Augustine searches for words through which to

1 It is important to underline that the "we" utilized throughout this passage refers specifically to Augustine and his mother. "She and I were standing leaning out of a window overlooking a garden," he writes. "We were searching together in the presence of the truth which is you yourself" (Confessions 9.10.23). "Our minds were lifted up," he continues; "step by step we climbed," he writes, "by internal reflection and dialogue" (Confessions 9.10.24). The religious experience exceeds the limit of Augustine as an individual: in this sense, the "we" in the text is not a matter of literary style but consociative.

\footnotetext{
* Corresponding author: Jessica Wiskus, Simon Silverman Phenomenology Center, Duquesne University, Pittsburgh, Pennsylvania, United States of America, e-mail: wiskus@duq.edu, wiskus@gmail.com
} 
articulate this shared experience with his mother ("therefore we said"), he admits that in this moment of ecstasy, "all language and every sign and everything transitory is silent." If they were to strain to listen to the remaining sounds above this silence, they would catch neither concepts nor images but music: the music of a psalm ("We did not make ourselves, we were made by him who abides for eternity"). "Having directed our ears," then, not to what God's creation might say, but to an awesome silence preceding the psalm, finally "we would hear his word" directly, and, "in a flash," attain "eternal wisdom."

Nearly two millennia after it was composed, Augustine's description remains evocative and powerful in its poetic force. And yet together with this evidence of Augustine's mastery of language stands his open reflection upon the nature - and limitations - of language itself. Augustine, though himself perhaps the finest orator of his generation, declares that the words he employs can in no way match the experience that he wishes to describe, for "human speech" moves through time (Confessions 9.10.24): "a sentence has both a beginning and an ending" (ibid.). By contrast, "wisdom itself is not brought into being but is as it was and always will be. Furthermore, in this wisdom there is no past and future, but only being, since it is eternal" (Confessions 9.10.24). Thus, the challenge of description is not simply a challenge for Augustine as a rhetorician; it is a problem pertaining to our fallen condition as mortal beings. What Augustine seeks is a means of expressing that would not succumb to temporal movement - would not fall into non-existence. "Eternal life" is what he wishes to describe (Confessions 9.10.25), but in searching for words, he confronts the essential distinction between the created and the eternal Creator. How can Augustine attempt to describe his religious experience, knowing in advance that any articulation would be decisively inadequate? He confesses, "But what is to be compared with your word, Lord of our lives? It dwells in you without growing old and gives renewal to all things" (ibid.).

And yet he proceeds, but in a very particular way. If his concern is that human language necessarily takes place in time - it has a beginning that falls away to oblivion and an ending that is not yet manifest - and so is incapable of expressing eternity, he nevertheless proceeds by way of a human expression that exceeds the momentariness of beginnings and endings, sewing together the indivisible instants of time: that is to say, by way of music. ${ }^{2}$ For in a song (or a psalm), every moment of meaning comes to us not isolated, fixed, or separate but through relation to what has been and will be; music sustains the flowing unity of time, through which even memory becomes anticipatory, renewed, and creative. If we listen carefully, we become aware that Augustine's description conveys more than conceptual content; he plays with the musical elements of language (i.e., prosody). His Latin is rich with tintinnabulations, through alliteration, anaphora, and internal rhyme:

\footnotetext{
Dicebamus ergo: "si cui sileat tumultus carnis, sileant phantasiae terrae et aquarum et aeris, sileant et poli et ipsa sibi anima sileat, et transeat se non se cogitando, sileant somnia et imaginariae revelationes, omnis lingua et omne signum et quidquid transeundo fit si cui sileat omnino - quoniam si quis audiat, dicunt haec omnia: Non ipsa nos fecimus, sed fecit nos qui manet in aeternum: - his dictis si iam taceant, quoniam erexerunt aurem in eum, qui fecit ea, et loquatur ipse solus non per ea, sed per se ipsum, ut audiamus verbum eius, non per linguam carnis neque per vocem angeli nec per sonitum nubis nec per aenigma similitudinis, sed ipsum, quem in his anamus, ipsum sine his audiamus, sicut nunc extendimus nos et rapida cogitatione attingimus aeternam sapientiam super omnia manentem” [...]
}

It is one, single stream of sound. Read it aloud, and listen. ${ }^{3}$ The only breath takes place when creation sings its praise: "We did not make ourselves, we were made by him who abides for eternity." It is a psalm within a veritable song, in the sense that its beginnings and endings are woven together so skillfully through phrase after phrase in

\footnotetext{
2 Compare this to his discussion of God's word that "is spoken eternally" (Confessions 11.7.9).

3 Paula Fredriksen explains, "Like all ancient people, Augustine thinks of words and texts orally, in terms of their being spoken and heard” (Fredriksen, “Autobiography,” 95). See, for example, Alberto Manguel's extended discourse on Augustine and Ambrose and the art of reading aloud in "The Silent Readers," of his A History of Reading. Indeed, spoken language is a constant concern for Augustine as he contrasts God's pronouncements in Genesis with the words spoken by living creatures (Confessions 11.3.5-11.7.9). Moreover, David Tell writes, "Augustine is insistent on this: his search for God in memory depends on the spokeness of his confessions" (Tell, "Mnemotechnics,” 247). Tell argues that this is what distinguishes Augustine's approach to memory from that of mnemotechnics. I would submit, however, that it is the musical aspect of spoken language that makes it an essential practice in recollection.
} 
relation that a single word extracted, out of place, would irrevocably alter the expression of the whole. Moreover, if we listen carefully, we become attentive to the way in which the Latin language makes use of quantifiable syllables; it is a language of duration, of measurement. There is a rhythm written into the words, and this is the aspect of language that is fundamentally musical. This rhythm is not a stress; it is not an emphasis that occurs in the pronounced sound itself, as a specific quality. It is, rather, a kind of relation - a numeric relation - that comes through the whole of what is being pronounced, what might be pronounced, and what is no longer sounding. Rhythm emerges in relation, one could say, to silence (i.e., to what might be and what is no longer). Augustine gives a robust example in Book XI, where he quotes Ambrose's hymn:

"God, Creator of all things" - Deus Creator omnium - the line consists of eight syllables, in which short and long syllables alternate. So the four which are short (the first, third, fifth, and seventh) are single in relation to the four long syllables (the second, fourth, sixth, and eighth). Each of the long syllables has twice the time of the short. As I recite the words, I also observe that this is so, for it is evident to sense-perception. To the degree that the sense-perception is unambiguous, I measure the long syllable by the short one, and perceive it to be twice the length. But when one syllable sounds after another, the short first, the long after it, how shall I keep my hold on the short, and how use it to apply a measure to the long, so as to verify that the long is twice as much? The long does not begin to sound unless the short has ceased to sound. I can hardly measure the long during the presence of its sound, as measuring becomes possible only after it has ended. When it is finished, it has gone into the past. What then is it which I measure? Where is the short syllable with which I am making my measurement? Where is the long which I am measuring? Both have sounded; they have flown away; they belong to the past. They now do not exist (Confessions 11.27.35).

Let us grant as evident, to Augustine, the impossibility of measuring what does not exist. And yet, he insists, "I offer my measurement and declare as confidently as a practiced sense-perception will allow, that the short is single, the long double" (Confessions 11.27.35). And Augustine the expert rhetorician is right to insist upon this, for it is an important feature of his style. Such numerical relations are evident in the speeches that Augustine composes, and indeed these relations help to construct their order and power - they make it possible for Augustine to express something that exceeds what is given in the moment. But how, for the listener, does that work? How do we compare what we are given to what we are not given (i.e., to what is silent)? It seems that, in order to be measurable, something must remain after the vibrating syllable has dissipated. In a small and overlooked treatise that Augustine wrote early in his career, De musica, the master poses this very problem to his young pupil:

M. If, then, we look for that rhythmical or metrical art we use for making verses, do you think it possesses the numbers verses are made by?

D. I can't suppose anything else.

M. Whatever these numbers are, do they seem to you to pass away with the verses or to remain?

D. To remain, certainly.

M. Therefore, it must be agreed some things that pass away are made from some numbers that remain?

D. Reason forces me to agree (De musica 6.12.35).

These numbers that remain inspire the trajectory of our own inquiry into Augustine's descriptive method in the Confessions. For in De musica, musical rhythm expresses a specific temporal structure, one in which phenomena (or notes) do not merely pass away but in which their forms (or numbers) are sustained. Through rhythm, Augustine makes a study of perception, number, time-consciousness, and memory - central concerns, too, of his better known Confessions. ${ }^{4}$ Not coincidentally, De musica was composed by Augustine during the actual time of his conversion to Christianity; that is to say, its composition likely spanned the period of Augustine's life that saw the ecstasy at Ostia and, later, the death of his beloved mother. While the Confessions, written a decade later, recounts these events as "autobiographical" material - as episodic memories - De musica occupied his thought while these events were actually happening. I believe that De musica holds a key for

4 In the introduction to his translation of De musica, Robert Catesby Taliaferro writes, "For anyone reading the treatise On Music and then Books X and XI of the Confessions, the dovetailing of the themes is striking. Augustine remains a rhetorician. But, from the frivolous rhetorician that he was before his conversion, he becomes the real rhetorician, he who wins the outer to the inner man, the world to number, and the soul to its Redemption" (Taliaferro, De musica, 163). 
understanding Augustine's description of religious ecstasy in Book IX of the Confessions: it shows us why the description would have to be musical. I take that key to be Augustine's use of Ambrose's hymn, Deus Creator omnium - a hymn to which Augustine refers not only throughout De musica but also at important moments in Books IX, X (on memory), and XI (on time-consciousness) of the Confessions, as well. Augustine's analyses suggest that we must recognize the workings of a particular type of memory (not episodic memory) that would open us to that which transcends ourselves (i.e., the eternal) - a type of memory that can be cultivated through music's rhythms.

My central claim, therefore, is that the problem of the description of religious experience, for Augustine, is connected to the problem of time-consciousness, and that in order to bring these problems into clear understanding, particular attention must be paid to the type of flowing memory that characterizes musical rhythm. This study of memory will help us understand why, for Augustine, a description of divine encounter should turn to the silence (and not the stress or articulation) beneath or between the words of a psalm.

\section{De musica}

Composed a decade before the Confessions, Augustine's De musica occupies a neo-Platonic landscape and, in the final of six total books, attempts to marry the philosophical with the theological by interweaving quotations from the Gospels with his conclusions about the metaphysics of rhythm. But in the first book, Biblical references are nowhere to be found, and Augustine unabashedly draws upon a text of paramount importance to the neo-Platonic tradition, Plato's Timaeus, for the first book of De musica is about numbers and their properties. Augustine accords special attention to the numbers 1, 2, 3, and 4 - numbers that hold significant meaning in the Timaeus. Plato's text was (and is) famous for having outlined, in the course of a creation story pertaining to the universal soul or governing power of all matter, what is known as the tetractys - a double (lambda) structure of powers of two and powers of three, extended from unity (e.g., 1) through four levels (Timaeus 35b-c). While for neo-Platonists (and neoPythagoreans), the tetractys is accorded an almost mystical significance, for music theorists working after the Greeks until at least the era of the Baroque, the tetractys was well-known as the structural foundation of harmony; for, from this structure, it is possible to derive the mathematical ratios that generate the musical intervals of the diatonic collection (e.g., 2:1 as the perfect octave, 3:2 as the perfect fifth, 4:3 as the perfect fourth, and 9:8 as the whole step). That is to say, for music theorists from classical Greece to the Italian Renaissance, the tetractys passage of the Timaeus is about harmony - is about what we hear, in the present (i.e., taking harmony as the simultaneous sounding of different but complementary vibrations). For example, anvils striking in a smithy have harmony (as the legend of Pythagoras has it); church bells ringing together in a belfry have harmony.

But such harmonious clamor, according to Augustine, is not music. Music, he offers, "is the science of mensurating well” [modulandi] (De musica 1.2.2) - a somewhat opaque definition, to be sure, and the master's student is right to press Augustine for an explanation of modulandi. What emerges from their discussion is the centrality of movement to music; not the physical movement of dance: for if the performer "should move his limbs for no other reason than that they should be moved gracefully and harmoniously, we should say he was dancing and nothing more" (De musica 1.2.3). The movement that is central to music, Augustine continues, is "movement which is free, that is, is desired for itself and charms through itself alone" (De musica 1.2.3), and this, for Augustine, is temporal movement. Moreover, "Music is the science of moving well," he explains, "because whatever moves and keeps harmoniously the measuring of time and intervals can already be said to move well" (De musica 1.3.4). Music, above all else, must be described in terms of a "pleasing" measured movement (ibid.). Music flows. It unfolds through time. (We may think of monophonic chant as an appropriate example.) And so, in De musica, Augustine does something very interesting with Plato's material (and in contrast to other writers on music). He takes the structure of the tetractys and creatively applies those ratios not to harmony - as we might expect - but to rhythm (De musica 1.12.20-26). 
Indeed, rhythm [numerus] is the governing concern of De musica's investigations. (And it is important to note that in De musica, Augustine renders the Greek term, $\dot{\rho} v \theta \mu$ ós, by the Latin, numerus.) Rhythms, for Augustine, are "numerically ordered movements" (De musica 1.11.19) - movements that can be "related by numerical measurement" and are therefore rational, or "joined together" by ratio (De musica 1.9.15). What we must understand is that, for Augustine, rhythm does not simply consist in a momentary stimulus; it does not arise in one instant, e.g., as a crash, a flash, or a noise. For rhythm, as a numerical relation, is not in a note (i.e., as a quality specific to each independent vibration or frequency). In music, one note - i.e., the "first" note - does not stand in an instant on its own, complete and independent. We do not hear music that way. The flowing of time that characterizes rhythm transcends what we hold in the infinitely thin slice of the present moment, for even a "first" note takes its place as first in relation to the preceding silence even as it lays forth an unfurling melody to come. But that need not imply that the silence is therefore made present - stripped of its sense of having passed - in the "first" note; when we listen to a melody, we are not holding the first note in our minds at the same time as the preceding silence. In a certain sense, we might say that rhythm takes place beyond notes; rhythm lives in the silence beneath the music of a psalm.

More precisely, a rhythm is a complex of presence and absence - of what is and what is no longer or not yet (and thus its intimacy with silence); it is irreducible to a single sound-event or "part" of time. ${ }^{5}$ For example, a "now" articulation must be related to a moment of the already-past and the yet-to-come-future in order for a rhythm to be expressed (that is to say, in order for us to have music - i.e., "the science of mensurating well" - and not just sound sensation or noise). Augustine conceives of this temporal structure in terms of countable numbers. For Augustine, each number bears a specific relationship to the

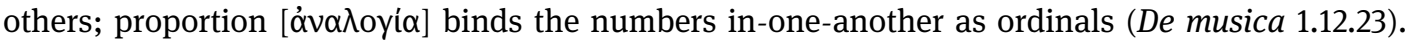

Hence, Augustine devotes much of Book I in De musica to an examination of the relationship between countable numbers. "For, since we are discussing numerically ordered movements, I wonder whether we first should not consider numbers themselves, and decide that whatever sure and fixed laws numbers make manifest are to be looked for and apprehended in the movements" (De musica 1.11.19). One of these laws, the master shows, is that "For something to be whole, it must consist of a beginning, middle, and end” (De musica 1.12.20). He continues:

M: Now tell me, then, in what number do you think a beginning, middle, and end are contained.

D: I think you want me to say the number three, for three is one of those you are looking for.

M: You think right. And so you see there is a certain perfection in three because it is a whole: it has a beginning, middle, and end (ibid.).

The number one has no middle nor end; likewise, according to Augustine's reasoning, the number two has no middle nor end (although it seems that it might have a beginning and a middle, there can be no middle without an end, but nor can there be a beginning and an end without a middle); the number two is a "second beginning," derived from the first because "one and one are two" (De musica 1.12.21). And it is these "two beginnings of numbers added together" that "make the whole and perfect number," i.e., the number three (De musica 1.12.22).

If these observations seem uninteresting to us, we must be careful here, because, according to Augustine, three is not merely the sum of its two countable predecessors; one and two are not independent parts of the number three, because the parts of three (i.e., beginning, middle, and end) do not exist independently: they exist only within the perfect whole that is three. That is to say, since, for Augustine, one is a beginning but the number two is also a beginning (and not a middle), we cannot imagine all three numbers laid out along a line, as it were, and imagine chopping each part out separately, as if one were the beginning and two the middle and three the end; rather, the number three is beginning, middle, and end

5 In Book III, Augustine distinguishes between rhythm and meter; meter has to do with the fixed "measure" or "rational composition of feet" (De musica 3.1.2). But rhythm [numerus] is the movement or "rolling forward" of succession itself - that is to say, the temporal flow (ibid.). Augustine describes it as "a sort of continuing number without definite end, as when chorusboys beat castanets and cymbals with their feet according to numbers whose combinations are pleasing to the ear, but yet in an unending flow" (De musica 3.1.1). 
together as a unity - it is a "great harmony" (De musica 1.12.22). And Augustine goes on to show that the first three countable numbers are bonded together through proportion [analogia] insofar as the "means agree with the extremes, and the extremes with the means" within the ordered set (ibid.). And so, it is not the numbers taken singly but the total set (i.e., $1,2,3)$ that exhibits this extraordinary sense of unity.

This extended discourse on the properties of number - the very numbers that comprise Plato's tetractys in the Timaeus - belongs to a treatise on music only insofar as we remember that numbers are countable: they are pronounced through time. So, too, in music, a rhythm, as "numerically ordered movements" (De musica 1.11.19) has three parts: the note (or silence) that has passed, the note that is sounding, and the note (or silence) that is to come. It is these three together (but not reducible to one - not reducible to the present) that make a rhythm. That a rhythm is a whole of distinct but non-independent parts (of a beginning, a middle, and an end) is key to grasping the reason why we have the sense of music flowing while it is flowing: we do not have to wait until the end of a musical phrase (i.e., when we might make present all the notes through our memory) in order to perceive rhythm as a whole gesture, encompassing notes that have passed and notes to come: we experience rhythm as a whole through its parts, while it is still in the process of unfolding. ${ }^{6}$ Therefore, it is not that we have this sense of the flowing movement of rhythm, thanks to the stitching together of independent moments, one outside of the next, through episodic memory. (It is not that the instants of time, constantly falling into oblivion, provide elemental matter for the mind's synthesis of before, now, and after; rather, it is rhythm that makes possible the differentiation of instants of time.) That is to say, counting, measurement, or mensuration itself-through the ordinal number of the movement of musical notes (e.g., first, second, and third) - discloses the existence of a whole in which what-is-no-longer and what-is-yet-to-come bear expressive meanings. Rhythm originates time. Or, to put it more boldly, rhythm precedes time itself.

And so, Augustine's little treatise on music which, in the centuries that followed its composition was often dismissed as an inconsequential work, can, on the contrary, be seen to investigate provocative philosophical questions. Our reading suggests why Augustine - a man of towering intellect - would be so concerned with a technical musical matter such as rhythm. When he claims, in Book VI, that by reciting Deus Creator omnium, he will "pass from corporeal to incorporeal things" (De musica 6.2.2), we would do well to take him seriously, since the final book of De musica marks out an ascent from the beauty of corporeal rhythms to an understanding of equality itself by which "with a restored delight in reason's numbers, our whole life is turned to God" (De musica 6.11.33). For even though the sounds of the notes in music are always passing away, the equality - the rhythmical relation of numbers that Augustine has investigated throughout the preceding five books of his treatise - is eternal. "Nothing at all is surer for me," declares his student, "than their equality" (De musica 6.12.36). The master presses further:

\footnotetext{
M: From where, then, must we believe what is eternal and unchangeable to be given the soul if not from the eternal and unchangeable God?

D: I don't see what else to believe.

M: Well, then, isn't it evident he, who under another's questioning moves himself within to God to know the unchangeable truth, cannot be reminded by any outside warning to see that truth, unless his memory hold his own same movement?

D: It's evident (ibid.).
}

\footnotetext{
6 A study of the relation between parts and wholes - i.e., mereology - is also what gives rise to many of Edmund Husserl's important insights in the Logical Investigations and, arguably, his On the Phenomenology of the Consciousness of Internal Time (1893-1917), a text in which melody is frequently used as a basis for the analysis of time-consciousness. That Husserl was well aware of Augustine's work on the problem of the flowing of time in Book XI of the Confessions is evident in Husserl's insistence at the opening of his lectures that, "Even today, anyone occupied with the problem of time must still study Chapters 14-28 of Book XI of the Confessions thoroughly" (Husserl, Consciousness of Internal Time, 3). Augustine, however, also gives an extended discussion of the relations between parts and wholes of time in Book IV, precisely where he introduces Ambrose's hymn, Deus Creator omnium in the Confessions for the first time (Confessions 4.10.15-4.11.17).
} 
That this truth is held within memory tells us that the path to God is to be undertaken by means of movement within the self. It is Augustine's reinterpretation of the ancient doctrine of anamnesis. At last, we see why Augustine would exhaust himself about the details of metrics and rhythm - he is searching in his memory for God. And yet the hint of this, we should have gathered from the very first book; for when the loyal pupil, frustrated by the complexity of issues that the master has revealed to him, asks that Augustine “explain” to him the nature of music (De musica 1.6.12), the Master graciously replies, "I shall do so," but then he adds, significantly: "Or rather you will do so. For all I shall do is question you. And by your answers you will explain all of what you now seem to be after, without knowing it” (De musica 1.7.13).

In this brief and apparently inconsequential dialogue between student and teacher, Augustine, however, reveals his method - anamnesis - and his reason for writing De musica as a dialogue. ${ }^{7}$ A method of internal reflection, anamnesis involves the recollection or recovery of knowledge; anamnesis undertakes a special kind of remembering - not a process of recovering episodic memories, or semantic memories, or implicit (i.e., motor) memories, but a remembering of what one never experienced. For example, the master never teaches the student this knowledge but only leads the student to recover the knowledge from within himself, through gentle (but insistent) prompting. This is the method that Augustine employs throughout his treatise, and it culminates in Book VI with a dialogue on rhythm in relation to the four cardinal virtues - for the meaning of virtue is not evident externally, in phenomena that pass (i.e., in experience) but must be recovered from within oneself. ${ }^{8}$

In De musica, anamnesis plays more than a methodological role, however; in the chapters that follow this declaration of method, Augustine sets about demonstrating the power that numbers play in creating the rhythmical structure-the ordered, temporal whole-upon which anamnesis depends. For the counting of the sequence of numbers does not only march forward to a limitless infinity; "I am now waiting anxiously to learn about the ratio which forces such an infinity back into some measure," the student confesses (De musica 1.11.19). It is an important property of numbers that, in the process of counting, there is a return - a retrospective movement. As Augustine replies:

Then, if you will, let us start considering numbers from the very beginning and see, as far as we can grasp such things with the mind's strength we have, what the reason [ratio] is that, although as we have said numbers progress to infinity, men have made certain articulations in counting by which they return again and again to one, the beginning or principle of numbers (De musica 1.11.19).

The number that performs this function, of course, is $10 .{ }^{9}$ It is important to point out, moreover, that this return, as Augustine describes it, is not merely a repeat of what was; it is creative: it reveals something new.

7 Augustine is indebted, in this respect, to the Platonic doctrine expounded in the Meno, as well as its style of exposition. Socrates demonstrates that Meno's slave has the capacity to recollect a knowledge of geometry, "without anyone having taught him, and only through questions put to him [...] recovering the knowledge out of himself" (Meno 85d). It is telling that Socrates demonstrates the power of anamnesis with respect to geometry, since geometry is an ordered science in which relations of spatial length are examined. (Music, as the third subject of study known, in the Medieval ages, as the quadrivium, follows geometry in the sense that it concerns the measurement of ordered time intervals.) But the crucial distinction between Augustine and Plato is that Augustine does not accept the doctrine of metempsychosis, whereby the knowledge to be recovered by anamnesis was given to the soul in a past life. For Augustine, this knowledge comes to us, not thanks to a previous life of the soul, but thanks to God, who, as supreme and eternal being, transcends all boundaries of what we, ourselves, experience in life.

8 On rhythm and the cultivation of virtue in Book VI of De musica, see Wiskus, "Rhythm and Transformation," 334-335.

9 Since Book I of De musica is heavily influenced by Plato's Timaeus, and Augustine's attention to number can be understood as an exposition of the ideas about number that spring from that work, the number 10 as represented by the tetractys should be understood as a Pythagorean symbol of unity. (See, for example, "Excursus B" in Kalvesmaki's The Theology of Arithmetic for remarks on the tetractys in the reception of the Pythagorean tradition; I am grateful to an anonymous reviewer for suggesting this reference.) More pertinent to Augustine's development of these ideas in the Confessions is Dmitri Nikulin's observation that "In the Pythagorean school, which was congenial to Plato's attitude toward mathematics as clarifying the meaning of being, Philolaus (ca. 470-390 BCE) argued that the decad, which is the completion of number, can be called memory (mnēmē). The reason for this is that the decad and its constituents allow us to achieve a firm understanding of being, which is also why the monad, the indivisible basis of number, can be called memory as well (mnèmosynē, fr. A13 DK)” (Nikulin, Memory, 50). 
For example, let us say that we proceed in counting up to the number 100; at the moment that we declare, "one-hundred," there exists a specific (retrospective) relationship to the number 10 (e.g., as Augustine puts it, "as ten contains one ten times, so a hundred contains the same ten ten times," ibid.). But equally we must say that the number 10 bears within it the (anticipatory) potential for 100. It is therefore not only that the number 100, when pronounced, exhibits a specific property in relation to a number, 10, that was previously articulated in the series - not only, that is to say, that the number 100 discloses a certain property about itself; it is that, moreover, upon the counting of 100, the number 10, too, becomes, in a sense, new: it is shown now to have a certain relationship to 100. These articulations of tens not only reveal a looping back - a numerical relationship between a present and a past number in the sequence of counting - but also an ever-creative potential for discovery, i.e., for the recovery of something previously unknown about a number that was pronounced in the past. It is this unified, rhythmical flowing that makes possible the act of anamnesis - that undergirds, that is to say, Augustine's method in De musica.

And the method matches the subject, for indeed, this creative, expressive span along the dynamic ordinal pronouncement - this rhythmical structure - shows us also how music moves: through temporal relation, and especially reconfiguration and re-initiation. In a melody, notes seem to move "up and down" in a flowing relation with each other; their sense emerges through an ever-changing relation to what has been, what is, and what might come: e.g., a motif that we heard a moment ago takes on new power - new affective meaning - as phrases flow on. ${ }^{10}$ In this way, each of the notes form (non-independent) parts of the whole.

The decisive way in which the whole, rhythmical structure accords to each of its previous parts a new sense suggests that we may characterize this flowing unity as a special kind of memory. What shall we call it? It is not the memory of things that I have experienced (e.g., episodic memory), not the memory of things that I have learned (e.g., semantic memory), nor the memory of actions that I have performed or undergone (e.g., implicit memory). It is, rather, the memory of order; it precedes (in origin) the differentiated pulse of time itself:1" it is "a vital movement serving the Master of all things, having in its numbers [rhythms] no temporal spans divided out, but with a power providing times" (De musica 6.17.58). In the same way that the perfect number three is a whole of non-independent parts, I shall describe this as a "perfect" memory - a memory of the all.

\section{Confessions}

What do I mean when I describe this special kind of memory? It is instructive to read De musica in light of Augustine's more famous account of memory in the Confessions. For the Confessions is, in sum, a work of memory (and not just because it is the so-called "autobiography"). ${ }^{12}$ Book X provides an agonizingly thorough analysis - and rightly so, for as Augustine writes, "in the vast hall of my memory" every experience is contained (Confessions 10.8.14). But not only the experiences themselves imprinted upon the

10 The sequence of pitches that we discern in a given melody - i.e., the "up and down" movement of notes - is dependent upon a rhythmical relation: sounds that begin and end in moments of time. Indeed, this is why Augustine's De musica, concerned not with melody but with rhythm, can nevertheless still be considered a treatise on "music": because it addresses that which is most fundamental to musical expression - temporal relations.

11 Priority of origin, Augustine, clarifies, is like the way in which "sound is prior to song." He explains, "When a song is sung, the sound is heard simultaneously. It is not that unformed sound comes first and is then shaped into song. [...] It is not prior in time. It is emitted at the same time as the song. It is not prior in preference, for sound is not something preferred to song, seeing that song is not merely sound but also beautiful sound. But there is priority in origin; for song is not endowed with form to become sound, but sound receives form to become song" (Confessions 12.29.40).

12 Although the Confessions, today, is often described as Augustine's "autobiography," I wish to underline the inadequacy of this characterization; the Confessions is a work of memory, but its investigations are not limited to the kind of memory - episodic memory - that has to do with experiences undergone by the individual (e.g., Augustine). Indeed, the aim of the work is to overcome what has been experienced and has passed away; the aim of confession (as opposed to autobiography) is forgiveness. 
mind like a series of images in a film. Together with those experiences, the one who experiences is retained: "there also," Augustine writes, "I meet myself and recall what I am." (In this sense, the self, for Augustine, is grounded not in an "I think" but in an "I remember.")

Memory, however, is not simply about the past; while it is true that we can remember (in the present) an event of the past, Augustine observes that memory contains even "future actions and events and hopes," insofar as his mind has the capacity to "combine with past events images of various things" as it concerns itself with what it believes might be to come. To want or to desire something, as well, is to remember it - how else would one know what it is that one desires? Moreover, memory, according to Augustine, contains not only the presence of images but even their absence-how else would we recognize that a thing has been forgotten (e.g., as in a name that lies just on the tip of your tongue - that which you know you have forgotten)? While to recognize that a thing is forgotten is to hold its absence in one's memory, also the perception of new things is dependent upon memory-how else would we recognize them as new, except in contrast to what we had known before? In this sense, cognition is necessarily a kind of $r e$-cognition: "By thinking we, as it were, gather together ideas which the memory contains in a dispersed and disordered way, and by concentrating our attention we arrange them in order as if ready to hand" (Confessions 10.11.18). To think is to remember. ${ }^{13}$ Indeed, "everything I am speaking of," he realizes, is "drawn out of the same treasure-house of memory." Thus, he concludes, "This power of memory is great, very great, my God. It is a vast and infinite profundity" (Confessions 10.8.15).

In Book X, Augustine makes a very patient accounting of the different types of memory at work in our lives. But the one that seems to be the most mysterious for him is the kind of memory that would lead us to God, for this would be a kind of memory that had not been constituted by means of what we knew or what we experienced: it would be a memory of precisely what transcends all experience. To think God according to experience - e.g., episodic memory, etc. - would be to miss God; it would be to think in parts when what one searches for is the whole. Accordingly, Augustine strives to surpass the ephemeral contents of memory (of events that have passed); only in this way can he move toward God: "Here I am climbing up through my mind towards you who are constant above me. I will pass beyond even that power of mind which is called memory, desiring to reach you" (Confessions 10.17.26), since it is evident to him that God cannot be contained within his mind. God is not the image of an object among objects, like a coin for which we search after having accidentally dropped it to the floor. As Augustine relates:

I recall myself to have searched for and found many lost items. From this experience I know that, when I was searching for one of them and someone said to me, "Perhaps this is it, perhaps that is," I would always say "No" until I was offered the object which I sought. Unless I had it in my memory, whatever it was, even if an offer was being made to me, I would not have found it because I would not have recognized it (Confessions 10.18.27).

Memory is the ground of knowledge; as Augustine had already shown, cognition is necessarily a re-cognition, whereby what is encountered becomes cognized in relation to what had passed before. But if we believe that memory is only about objects or experiences or acts that have passed away and are no longer, then God cannot possibly be in memory. Yet if Augustine reaches beyond his own memory, then how would he recognize God? How would he know that it was God he encountered, if he had no means by which to recognize Him as such? "As I rise above memory, where am I to find you?" he complains.

13 We may compare this, again, to the process of anamnesis, for thinking (cognition) is a matter of re-ordering and recollecting what once was known. Augustine explains that ideas "have to be brought together [cogenda] so as to be capable of being known; that means they have to be gathered [colligenda] from their dispersed state. Hence is derived the word cogitate. To bring together [cogo] and to cogitate [cogito] are words related" (Confessions 10.11.18). And it is the similarity of their sonic pronouncement that, for Augustine, demonstrates their conceptual relation. Moreover, order - we may say, the countable, flowing order of perceptions - is the essence of this gathering together: "Where there is no form, no order, nothing comes or goes into the past," Augustine writes in Book XII (Confessions 12.9.9). Because of the temporal unfolding of thought, memory is necessary for understanding. In De Trinitate, he writes, "But now I am referring to understanding [intellegentiam] as that whereby we understand [intellegimus] when actually thinking [cogitantes], that is, when our thought is formed after the finding of those things which had been present in our memory, but of which we were not thinking” (De Trinitate, 14.7.10). 
"If I find you outside my memory, I am not mindful of you. And how shall I find you if I am not mindful of you?" (Confessions 10.17.26).

Augustine desires to know God; he wants to reach precisely that which is ungraspable - that which transcends the very thing - memory - that would make a cognitive grasp possible. Puzzling through this contradiction, he examines the way in which men and women eagerly insist upon their desire for a happy life without ever having possessed it themselves (so that they could not recognize it if they stumbled upon it). "Is not the happy life that which all desire, which indeed no one fails to desire? But how have they known about it so as to want it? Where did they see it to love it?" (Confessions 10.20.29).

What concerns Augustine here is the question of how something (e.g., happiness) that is neither a part of present experience nor a part of past experience can yet give shape to the aim and the meaning of the whole of one's life. "But then I ought to say how my quest proceeds; is it by remembering, as if I had forgotten it and still recall that I had forgotten? Or is it through an urge to learn something quite unknown, whether I never had known it or had so forgotten it that I do not even remember having forgotten it?" (ibid.). What Augustine wants to recollect is that which was never experienced; the way to do this, as we learned in De musica, is through anamnesis, a process of recollecting that depends upon a flowing unity or rhythmical whole - depends upon what I am calling a "perfect" memory - depends not upon the content of individual experiences but rather their numerical order. For, as De musica showed, the countable numbers exhibit extraordinary relationships through which they are bound as unities; also in the Confessions, Augustine writes, "I mention the numbers by which we count things. It is remarkable that in my memory are present not their images but the numbers themselves" (Confessions 10.15.23). These numbers - rhythms - do not pass away, for the flowing movement of perfect memory is a tightly bonded relation of past, present, and future (like the proportion that unifies the perfect number three). And this means that Augustine must expand the careful study of memory that opens Book X; beneath the memory of events, of things, or of capacities (all of which he describes so well by examples), is a memory of the whole - a memory of order, of number. It is a memory of perfection, of everything that is good and pleasing (but that is not contained in the things of experience); it is the memory of God. "You conferred this honour on my memory that you should dwell in it" (Confessions 10.25.36). And he cries out:

And see, you were within and I was in the external world and sought you there, and in my unlovely state I plunged into those lovely created things which you made. You were with me, and I was not with you. The lovely things kept me far from you, though if they did not have their existence in you, they had no existence at all. You called and cried out loud and shattered my deafness. You were radiant and resplendent, you put flight to my blindness. You were fragrant, and I drew in my breath and now pant after you. I tasted you, and I feel but hunger and thirst for you. You touched me, and I am set on fire to attain the peace which is yours (Confessions 10.27.38).

It is, once again, a remarkable passage, crafted of rhyme and rhythm in an extraordinary Latin. In his performance of language, therefore, Augustine confirms the kind of memory in which he finds God - it is the same kind of memory (he confirms at the end of Book XI) that we engage when we sing.

When I sing, I recognize a musical note as musical, as rhythmical, as expressive even while it is unfolding - even while I have no representation or image of the total phrase (of the notes that were and that will be); in the moment, I recognize that I perform a part of a dynamic whole, even though I can have no experience of that whole all at once. Precisely because rhythm evokes this transcendent whole, musical rhythm - the silent movement beneath a psalm - according to Augustine in Book IX, is the most suitable description of divine transcendence. And, in Book XI, it is indeed to music that he turns when trying to express what he has come to know of God:

Suppose I am about to [perform] a psalm which I know. Before I begin, my expectation is directed towards the whole. But when I have begun, the verses from it which I take into the past become the object of my memory. The life of this act of mine is stretched two ways, into my memory because of the words I have already said and into my expectation because of those which I am about to say. But my attention is on what is present: by that the future is transferred to become the past (Confessions 11.28.38). 
The passage is well-known, and yet the formula that it is intended to illustrate - that "there are three times, a present of things past, a present of things present, a present of things to come" (Confessions 11.20.26) - cannot be interpreted as a reduction of all things past and future to the present. ${ }^{14}$ It is instructive that, in the text, Augustine actually performs the hymn Deus Creator omnium: he does not merely refer to it but employs it to evoke the very sense of flowing, temporal unity that he wishes to describe. He has a present of pastness and a present of futureness while he is singing Deus Creator omnium, in the same way that, while he is counting a sequence of numbers in De musica, he observes that three, as the first perfect number, has a beginning, middle, and end although it is irreducible to any one of these parts. This is the structure of perfect memory: a whole constituted of that which exceeds the present - a whole that is not fixed but is flowing, dynamic, and, as in the cycle of tens, carries the potential for creating new relationships. Thus, he writes:

Certainly if there were a mind endowed with such great knowledge and prescience that all things past and future could be known in the way I know a very familiar psalm, this mind would be utterly miraculous and amazing to the point of inducing awe. From such a mind nothing of the past would be hidden, nor anything of what remaining ages have in store, just as I have full knowledge of that psalm I sing (Confessions 11.31.41).

It is Augustine's description of the mind of God; and we may not be too far off if we suppose that Augustine's singing of Ambrose's hymn - during the very period in his life when he was composing De musica - helped ensure that he would recognize God when the moment of divine encounter would come at Ostia. ${ }^{15}$

\section{Rhythm and forgiveness}

It is notable that this religious ecstasy at Ostia is not a solitary but a shared experience (e.g., with his mother, Monica). How often, in the history of Christianity, is an experience like this undergone by two people, together? For clearly this is not a higher journey that Augustine undertakes independently; Augustine and his mother are intimate companions in the search for God. He writes:

Our minds were lifted up by an ardent affection towards eternal being itself. Step by step we climbed beyond all corporeal objects and the heaven itself, where sun, moon, and stars shed light on the earth. We ascended even further by internal reflection and dialogue and wonder at your works, and we entered into our own minds [venimus in mentes nostras et transcendimus eas]. We moved up beyond them so as to attain to the region of inexhaustible abundance where you feed Israel eternally with truth for food (Confessions 9.10.24).

How might they have entered into their "own minds" and transcended them, so that together, through "a moment of total concentration of the heart," they might have "touched" the eternal (ibid.)? It is as if

14 On the other hand, when he insists that "both the past and the future do exist" (Confessions 11.17.22), Augustine is not claiming existence for what has passed or what is yet to come. Paul Ricoeur clarifies that in this passage, "the terms for past and future henceforth appear as adjectives: futura and praeterita. This nearly imperceptible shift actually opens the way for the denouement of the initial paradox concerning being and nonbeing and, as a result, also for the central paradox of measurement" (Ricoeur, Time and Narrative, 10). What can be measured are not events, experiences, or things but, I am claiming, numbers. Ricoeur puts it this way: "We are in fact prepared to consider as existing, not the past and the future as such, but the temporal qualities that can exist in the present, without the things of which we speak, when we recount them or predict them, still existing or already existing" (ibid.). Although Ricoeur makes no mention of De musica in his analysis, we can see that Augustine's turn to the psalm as a means of addressing this paradox is fitting, since music as "the science of mensurating well" (De musica 1.2.2) constitutes the proper science for temporal measurement.

15 Indeed, scholars have long recognized the essential role that the psalms play in Augustine's Confessions. Jeffrey S. Lehman writes, "The presence of the Book of Psalms in St. Augustine's Confessions is extensive and unmistakable; from the opening lines, citations of or allusions to individual psalms occur on virtually every page. Given the ubiquity of such references, readers have long recognized the fundamental importance of the Psalms for understanding Augustine's unique project” (Lehman, "On the Psalms,” 160). See also Burns, “The Role of Music," 133. 
their hearts and minds are united - are one - in this effort. How? We normally think of consciousness as something separate, individual, even opaque. How could these two individuals experience as one?

We must keep in mind that it is not just any person with whom Augustine shares this ecstasy: he shares it with his mother - the very one who, in the first place, prayed for Augustine to become a Christian, and who wanted nothing more from life than to see this prayer granted. Indeed, Augustine the narrator tells us (just before relating the event of the shared ecstasy at Ostia) that, unbeknownst to him, "The day was imminent when she was to depart this life" (Confessions 9.10.23). In a sense, her companionship with Augustine at the moment in Ostia was her final act of delivering the evidence of truth to him (the truth to which she, herself, had born witness throughout the actions of her life). Indeed, she says to him afterward:

My son, as for myself, I now find no pleasure in this life. What I have still to do here and why I am here, I do not know. My hope in this world is already fulfilled. The one reason why I wanted to stay longer in this life was my desire to see you a Catholic Christian before I die (Confessions 9.10.26).

And she dies some days later, having seen her wish fulfilled. Yet it is clear that the ecstasy at Ostia was not, in a sense, for her; it was not a sign of assurance for her. Her faith was unwavering throughout her life, and she had no doubts as to the unsurpassable delight that heaven would offer to her; rather, it seems that Augustine and Monica shared the ecstasy so that, once more, the mother could deliver a truth to her son.

It was the mother, after all, who - presumably from the time that she had learned that she was with child - had so fervently hoped that this new life within her would also know of God's goodness. That Monica carried this faith inside of her while Augustine was conceived and growing - was not this a source of his memory of God, or, more precisely, the source of a memory of God that transcends the boundary of his own episodic memory? Augustine himself considers the possibility, crying out, "Tell me, God, tell your suppliant, in mercy to your poor wretch, tell me whether there was some period of my life, now dead and gone, which preceded my infancy? Or is this period that which I spent in my mother's womb?" (Confessions 1.6.9). For in a concrete sense, Augustine's memory predates the moment of his own birth as an individual; from the moment that an infant is delivered of its mother, already it has hunger - it desires milk (Confessions 1.6.7). It wants; it wants what it does not now have. After the moment of birth, the infant cries, and Augustine relates: "I threw my limbs about and uttered sounds" (Confessions 1.6.8). But how could he have known that something was lacking, except by reference to a previous state in which he had felt satiated? Therefore, there must be some kind of memory involved in the desire. We cannot assume that such memory would be restricted to the beginning of an individual's own life, which we mark as the moment of separation from the mother. ${ }^{16}$ Somehow, the memory of Monica (while her child is still in the womb) can be understood as bound together with the memory of Augustine (who is recognized as an individual just after the moment of delivery). Hence, it is entirely fitting that, in Book I, Augustine's first investigation of memory would be through a reflection upon the infant's relation to his mother; his most poignant understanding of that memory, in Book IX - the final book of the "autobiographical" portion of the Confessions, after which his discourse transcends the limits of episodic memory - is related to his mother, as well.

In Book IX occurs what may be viewed as the greatest emotional release of the Confessions - the moment after the ecstasy at Ostia and after Monica's death - the moment when, finally, Augustine is able to weep for his beloved mother. Alone in his bed, he recalls the first two verses of Deus Creator omnium:

16 Modern studies confirm that from the instant that an infant is born, he or she is able to recognize the mother's voice: its prosody (see, for example, Nazzi and Ramus, "Linguistic rhythm," 236). It is not that the infant recognizes concepts - the meaning of what the mother says - but that the infant recognizes the movement (up and down) and the rhythm, the lilt and the inflection, of the mother's voice. This recognition is a capacity that develops during the fetus' time in the womb, a time when mother and child listened to flowing sounds - to expressive wholes of past-ness, present, and future-ness - inseparably. Although we cannot make a rash claim that Augustine's listening with his mother at Ostia anticipated the findings of modern science, what we might say, reasonably, is that empirical evidence does not in any way undermine Augustine's description. 
Creator of all things

You rule the heavens

You clothe the day with light

And night with the grace of sleep

(Confessions 9.12.32)
So rest restores exhausted limbs

To the usefulness of work

It lightens weary minds

And dissolves the causes of grief

It is the only point in the "autobiographical" portion of the text when the hymn is not merely referenced but actually performed; Augustine sings, and by his singing the flowing whole of perfect memory is evoked. ${ }^{17}$ Dramatically, Augustine's grief dissolves. He writes: "Now I let flow the tears which I had held back so that they ran as freely as they wished. My heart rested upon them, and it reclined upon them because it was your ears that were there," he confesses to God (Confessions 9.12.33). The performance reconfigures the grief in his heart; it gives him the courage, finally, to fulfill a promise to Monica: he confesses her sins, petitioning God for forgiveness on her behalf. It may seem strange to us that Book IX - that magnificent book describing the height of ecstatic experience - comes to an end in this way. For what knowledge had he of Monica's sins? They were not his own. But, as he realizes through his singing, the flowing whole of perfect memory is what underlies forgiveness. And this is what Augustine shows us as the "autobiographical" account comes to an end: a son beseeches forgiveness from God for the sins of another - sins of which he, himself, had no experience. It is a gesture that utterly transcends Augustine as an individual - an act that had been undertaken long before him (e.g., Luke 23:34).

For confession, as Augustine's title suggests, carries a dual sense, and both meanings are at work here. ${ }^{18}$ It is not only that, through confession, there is a recounting of the past in the sense of a description of past events; confession, as a rhythmical, transformative process, effects a reorientation toward the past. To confess is to recollect one's sins, yes, but more than that: also, through singing the praises of God, to recognize - to re-cognize - and to re-order the sense of a whole. ${ }^{19}$ It is through this process of recollection that something new - forgiveness - emerges.

In the books that follow, therefore, the "autobiographical" style is abandoned, effecting a kind of erasure of Augustine the narrator; no longer recounting the events of his past, these books surpass the boundaries of his life as an individual, focusing relentlessly on the relation between the eternal and the created - between that which is whole and the multitude of its parts. For, in the end, all of these are constituted rhythmically. One's life, according to Augustine, takes the form of the performance of a psalm, in which one experiences an ever-flowing, rhythmical meaning. Moreover, the transcendence at work in this structure is the same as that which binds together not only the whole of one's life but also the whole of humanity - of human being across the ages. Augustine writes:

What occurs in the psalm as a whole occurs in its particular pieces and its individual syllables. The same is true of a longer action in which perhaps that psalm is a part. It is also valid of the entire life of an individual person, where all actions are parts of a whole, and of the total history of 'the sons of men' (Ps. 30: 20) where all human lives are but parts (Confessions 11.28.38).

17 It is entirely appropriate that Deus Creator omnium figures into Augustine's mourning of his mother; Monica's own "enthusiasm for Ambrose's music is glimpsed in one of Augustine's dialogues from Cassiciacum where she contributes a quote from the Ambrosian hymn Deus Creator omnium," Brian Brennan tells us (Brennan, “Augustine’s De musica," 268). The work in which this occurs is De Beata Vita.

18 Lehman clarifies, "In addition to the more common usage of confession as 'acknowledgement of sin' (confession peccatorum) confession can also be used to mean 'proclamation of praise' (confession laudis)" (Lehman, "On the Psalms," 172). 19 That it is singing that effects this re-ordering is significant. Lehman writes, "Among the various purposes of Augustine's Confessions, arguably one of the most central is Augustine's attempt to portray the reordering of his desires so that his reader may follow in his footsteps, leading to the proper ordering of their own affections and enkindling their love for God. By attending to the performative element of Augustine's reading of the psalms, then, we gain valuable insight into the nature of his project in Confessions" (Lehman, “On the Psalms,” 164). 


\section{References}

Augustine. Confessions, translated by Henry Chadwick. Oxford: Oxford University Press, 1991.

Augustine. In On the Trinity: Books $8-15$, edited by Gary B. Matthews and translated by Stephen McKenna. Cambridge: Cambridge University Press, 2002a.

Augustine. On Music, translated by Robert Catesby Taliaferro. In The Fathers of the Church. Washington, DC: The Catholic University of America Press, 2002b.

Augustine. Confessions: Books I-VIII, translated by William Watts. Loeb Classical Library. Cambridge, MA: Harvard University Press, 2006a.

Augustine. Confessions: Books IX-XIII, translated by William Watts. Loeb Classical Library. Cambridge, MA: Harvard University Press, 2006b.

Brennan, Brian. “Augustine's De musica.” Vigiliae Christianae 42:3 (1988), 267-81.

Burns, Paul. "Augustine's Distinctive Use of the Psalms in the Confessions: The Role of Music and Recitation." Augustinian Studies 24 (1993), 133-46.

Fredriksen, Paula. "The Confessions as Autobiography." In A Companion to Augustine, edited by Mark Vessey, 87-98. West Sussex: Blackwell Publishing Ltd, 2012.

Husserl, Edmund. On the Phenomenology of the Consciousness of Internal Time (1893-1917), translated by John Barnett Brough. Dordrecht: Kluwer, 1991.

Kalvesmaki, Joel. The Theology of Arithmetic: Number Symbolism in Platonism and Early Christianity. Hellenic Studies 59. Cambridge, MA: Harvard University Press, 2013.

Lehman, Jeffrey S. “'As I read, I was set on fire': On the Psalms in Augustine's Confessions.” Logos: A Journal of Catholic Thought and Culture 16:2 (2013), 160-84.

Manguel, Alberto. A History of Reading. New York: Viking, 1996.

Nazzi, Thierry \& Ramus, Franck. "Perception and acquisition of linguistic rhythm by infants." Speech Communication 41 (2003), 233-43.

Nikulin, Dmitri. Memory: A History. Oxford: Oxford University Press, 2015.

Plato. Meno, translated by W. R. M. Lamb. Loeb Classical Library. Cambridge, MA: Harvard University Press, 2006.

Ricoeur, Paul. Time and Narrative, vol. 1, translated by Kathleen McLaughlin and David Pellauer. Chicago: University of Chicago Press, 1984.

Tell, David. "Beyond Mnemotechnics: Confessions and Memory in Augustine." Philosophy \& Rhetoric 39:3 (2006), $233-53$.

Wiskus, Jessica. "Rhythm and Transformation Through Memory: On Augustine’s Confessions After De Musica." Journal of Speculative Philosophy 30:3 (2016), 328-38.

Wiskus, Jessica. "On the Non-Independent Parts of Time-Consciousness: Husserl's Early Phenomenological Investigations and the Perception of Melody.” Music Theory Spectrum 43:1 (April 2021) forthcoming. 